\title{
Black soldier fly as dietary protein source for broiler quails: apparent digestibility, excreta microbial load, feed choice, performance, carcass and meat traits
}

\author{
M. Cullere ${ }^{1}$, G. Tasoniero ${ }^{1}$, V. Giaccone ${ }^{1}$, R. Miotti-Scapin ${ }^{1}$, E. Claeys ${ }^{2}$, S. De Smet $^{2}$ and \\ A. Dalle Zotte ${ }^{i \dagger}$ \\ ${ }^{1}$ Department of Animal Medicine, Production and Health, University of Padova, Viale dell'Università 16, 35020 Legnaro, Italy; ${ }^{2}$ Laboratory for Animal Nutrition and \\ Animal Product Quality, Department of Animal Production, Ghent University, 9090 Melle, Belgium
}

\begin{abstract}
In order to expand with validated scientific data the limited knowledge regarding the potential application of insects as innovative feed ingredients for poultry, the present study tested a partial substitution of soya bean meal and soya bean oil with defatted black soldier fly (Hermetia illucens) larvae meal (H) in the diet for growing broiler quails (Coturnix coturnix japonica) on growth performance, mortality, nutrients apparent digestibility, microbiological composition of excreta, feed choice, carcass and meat traits. With this purpose, a total of 450 10-day-old birds were allocated to 15 cages (30 birds/cage) and received three dietary treatments: a Control diet (C) and two diets ( $\mathrm{H1}$ and $\mathrm{H} 2$ ) corresponding to $10 \%$ and $15 \% \mathrm{H}$ inclusion levels, respectively ( $H$ substituted $28.4 \%$ soya bean oil and $16.1 \%$ soya bean meal for $H 1$, and $100 \%$ soya bean oil and $24.8 \%$ soya bean meal for $\mathrm{H2}$, respectively). At 28 days of age, quails were slaughtered, carcasses were weighed, breast muscles were then excised from 50 quails/treatment, weighed, and ultimate $\mathrm{pH}(\mathrm{pHu})$ and $\mathrm{L}^{*}, \mathrm{a}^{*}, \mathrm{~b}^{*}$ colour values were measured. Breast muscles were then cooked to assess cooking loss and meat toughness. For the digestibility trial, a total of 15 28-day-old quails were assigned to the three feeding groups. The excreta samples were subjected to chemical and microbiological analysis. The same 15 quails were then simultaneously provided with $\mathrm{C}$ and $\mathrm{H} 2$ diets for a 10-day feed choice trial. Productive performance, mortality and carcass traits were in line with commercial standards and similar in all experimental groups. With the exception of ether extract digestibility, which was lower in $\mathrm{H} 1$ group compared with $\mathrm{C}$ and $\mathrm{H} 2(\mathrm{P}=0.0001)$, apparent digestibility of dry matter, $C P$, starch and energy did not differ among treatments. Microbial composition of excreta was also comparable among the three groups. Feed choice trial showed that quails did not express a preference toward $\mathrm{C}$ or $\mathrm{H} 2$ diets. Breast meat weight and yield did not differ among $\mathrm{C}$, $\mathrm{H} 1$ and $\mathrm{H} 2$ quails. Differently, the inclusion of $\mathrm{H}$ meal reduced meat $\mathrm{pH}$ compared with $\mathrm{C}$. In conclusion, this study demonstrated that $\mathrm{H}$. illucens larvae meal can partially replace conventional soya bean meal and soya bean oil in the diet for growing broiler quails, thus confirming to be a promising insect protein source for the feed industry. Further research to assess the impact of $\mathrm{H}$ meal on intestinal morphology as well as on meat quality and sensory profile would be of utmost importance.
\end{abstract}

Keywords: insect meal, quail, performance, digestibility, feed choice

\section{Implications}

Insects represent a possible alternative nutrient source for the livestock sector which could help to face the rising demand and price for conventional feedstuffs in a more sustainable way. However, for developed countries, there is a lack of a clear legislation and standards guiding the use of insects as feed that hamper the industrial development of this emerging sector. This study demonstrated that insect

${ }^{\dagger}$ E-mail: antonella.dallezotte@unipd.it meal from Hermetia illucens larvae $(\mathrm{H})$ can partly substitute conventional ingredients in the diet for broiler quails, without impairing performance, carcass and meat traits. However, the impact of $\mathrm{H}$ on nutrients digestibility should be further studied.

\section{Introduction}

Trends toward 2050 predict a population increase to nine billion people, which will result in a $58 \%$ increase of global demand for meat compared with 2010 (Food and Agriculture Organization of the United Nations (FAO), 2013). 
This would require an increase in the livestock production and consequent augmented pressure on the environment with conceivable consequences on its already overexploited resources. In parallel, a rapid expansion in demand for soya bean/oil will increase prices, which would result in an estimated increase in prices for meat of $>30 \%$ by 2050 compared with 2000 (FAO, 2010). Therefore, it becomes evident that the search for alternative and sustainable feed alternatives for livestock is an issue of major importance. Regarding the poultry industry, a major key goal of the sector is to provide feeds containing all the necessary nutrients for birds to support production and maintenance, thus allowing them to express their genetic potential. Typical rations are cereal based and must be supplemented with adequate quantity of animal protein (fishmeal) or with essential amino acids (Sánchez-Muros et al., 2014).

In this scenario, insects represent a great opportunity to meet the demand and partly/totally replace conventional protein feed sources. In 2014, the FAO highlighted 'the need of further research efforts to provide and expand with validated data the available scientific evidence and benefits of using insects in the food and feed chains' (FAO, 2014). In fact, most published animal performance data, originate from studies conducted in Africa and Asia and focus only on some species. Consequently, studies in other regions using different husbandry systems and species are required to further explore the potential of insect ingredients in animal feed as well as to assess their effect on the quality of animal products. Insects are cold blooded, thus having a high feed conversion efficiency, they can be fed by-products whose elimination has an economic and environmental cost and they can be reared under different conditions to optimize their nutritive value (Sealey et al., 2011).

The black soldier fly (Hermetia illucens) is a Diptera of the Stratiomyidae family that historically comes from the New World but which can now be found worldwide from latitude $46^{\circ} \mathrm{N}$ to $42^{\circ} \mathrm{S}$ (Martínez-Sánchez et al., 2011). Larvae can grow on a wide range of decomposing organic materials, from fruits and vegetables to kitchen wastes, rendered fish and poultry, pigs and cattle manure, thus being potentially interesting in reducing environmental criticisms by transforming waste in valuable biomass (Nguyen et al., 2015). Moreover, insects are a part of the natural diet of wild birds and free-range poultry. Black soldier fly larvae can provide high-value feedstuff being rich in protein ( $40 \%$ to $44 \%$ ) with a better amino acid profile compared with that of soya bean meal (Tran et al., 2015). They have a high dry matter (DM) content (35\% to $45 \%)$, they are rich in lysine ( $6 \%$ to $8 \%$ of the $\mathrm{CP}), \mathrm{Ca}(5 \%$ to $8 \% \mathrm{DM})$ and $\mathrm{P}(0.6 \%$ to $1.5 \%$ DM) (Makkar et al., 2014). Black soldier fly larvae are also rich in fat which has an extreme quantitative $15 \%$ to $49 \%$ ) and qualitative variability depending on the chemical composition of the rearing substrate (St-Hilaire et al., 2007).

Even if in recent years some authors reported interesting results about the suitability of different types of insect meal as diet ingredients for pigs, poultry and different fish species (Veldkamp et al., 2012; Makkar et al., 2014), little information on the digestibility of insects in livestock species is available.
Moreover, only one recent study dealt with black soldier fly larvae meal as feed ingredient for poultry diets (De Marco et al., 2015) and pointed out that $H$. illucens meal is an excellent source of energy and digestible amino acids for broilers. Regarding the few papers dealing with growth performance, black soldier fly meal has been found to improve the growth rate of chickens as a component of a complete diet (Oluokun, 2000).

On the basis of the above-mentioned considerations, the present research aimed at studying the effect of a partial substitution of soya bean meal and soya bean oil with black soldier fly ( $H$. illucens) larvae meal in the diet for growing broiler quails on nutrients apparent digestibility, microbiological composition of excreta, feed choice, growth performance, mortality, carcass and meat traits.

\section{Material and methods}

\section{Insect meal}

The insect meal which was tested in the present study was obtained from defatted black soldier fly $(H$. illucens, $H$ ) larvae and it was purchased from a leading European company specialized in insects as nutritional source. Product safety and quality were guaranteed by hazard analysis and critical control points (HACCP) standards; in addition, the company will soon comply with the highest international feed safety standards, including good manufacturing practices (GMP+) and Trust Feed. Chemical composition, energy content and amino acid concentration of the $\mathrm{H}$ are shown in Table 1.

\section{Performance trial}

The study was performed in a private quail farm of the Vicenza province (Italy), and it was carried out after the approval by the veterinary authority and according to the article 2, DL 4 March 2014, No. 26 of the Official Journal of the Italian Republic (http://www.gazzettaufficiale.it/eli/id/ 2014/03/14/14G00036/sg), implementing the EC Directive 86/60963/2010 EU regarding the protection of animals used for experimental and other scientific purposes.

A total of 450 10-day-old quails (Coturnix coturnix japonica) of both sexes were weighed, marked and housed in batteries in an environmentally controlled room. The chicks were allocated by 30 in 15 cages and received three dietary treatments (five replicates per treatment) until slaughtering: a Control diet (C) which was formulated referring to the common grower diet, which was used in the farm, $\mathrm{H} 1$ and $\mathrm{H} 2$ diets in which conventional protein/fat sources were partly substituted with $\mathrm{H}: 10 \% \mathrm{H}$ for $\mathrm{H} 1$ and $15 \% \mathrm{H}$ for $\mathrm{H} 2$. In $\mathrm{H} 1, \mathrm{H}$ replaced $28.4 \%$ of soya bean oil and $16.1 \%$ of soya bean meal, whereas in H2 H substituted $100 \%$ of soya bean oil and $24.8 \%$ of soya bean meal. All diets were formulated to meet the minimum requirements for Japanese quails (National Research Council, 1994). Mashed feeds and water were provided ad libitum. Mortality was recorded daily. At the end of the experimental period, birds were individually weighed and feed consumption was recorded for feed conversion computation within replicate. Ingredients, chemical composition and energy content of diets are shown in Tables 2 and 3. 
Black soldier fly as feed for broiler quails

Table 1 Chemical composition, energy content and amino acid concentration ( $\mathrm{g} / \mathrm{kg}$ as fed) of the defatted Hermetia illucens larvae meal $(H)$

\begin{tabular}{lc}
\hline \hline & $\mathrm{H}$ \\
\hline Dry matter & 946.1 \\
CP & 518.1 \\
Crude fat & 147.8 \\
Ash & 72.7 \\
Gross energy (MJ/kg) ${ }^{1}$ & 21.81 \\
Indispensable amino acids & \\
Arginine & 16.4 \\
Histidine & 4.7 \\
Isoleucine & 22.4 \\
Leucine & 33.0 \\
Lysine & 19.6 \\
Methionine & 6.2 \\
Phenylalanine & 16.9 \\
Threonine & 19.3 \\
Valine & 35.8 \\
Dispensable amino acids & \\
Alanine & 46.4 \\
Aspartic acid & \\
Cysteine & 0.9 \\
Glycine & 44.3 \\
Glutamic acid & 45.2 \\
Proline & 29.1 \\
Serine & 21.3 \\
Tryptophan & \\
Tyrosine & \\
\hline \hline
\end{tabular}

${ }^{1}$ Analysed.

\section{Digestibility trial}

At farm, a total of 15 28-day-old broiler quails (C. coturnix japonica) were randomly selected and destined to an in vivo digestibility trial. Digestibility cages were provided by the Department of Animal Medicine, Production and Health (MAPS) of Padova University (Italy). Quails were individually weighed and divided into three experimental feeding groups with similar live weight (LW) and SD $(172.7 \pm 6.9 \mathrm{~g}):$ C, $\mathrm{H} 1$ and $\mathrm{H} 2$. Birds were individually caged and were subjected to 1 week of adaptation to the experimental diets during which individual feed intake was calculated. At the end of adaptation, quails were weighed again and, after $24 \mathrm{~h}$ fasting, they were fed their corresponding experimental diet for 3 days plus 1 day of fasting, so that the feed intake and excreta were accurately determined. The excreta samples were daily collected from each cage, carefully cleaned from feathers and feed, weighed, then promptly chilled. The excreta were freeze-dried, ground and stored at $+4^{\circ} \mathrm{C}$ until further analysis. Birds were refed with the same experimental diets and individual excreta were immediately subjected to microbiological determinations.

\section{Feed choice test}

At farm, after the digestibility trial, the 15 40-day-old quails were simultaneously provided with $\mathrm{C}$ and $\mathrm{H} 2$ diets only. After 3 days of adaptation to the new feeding condition, a 10-day feed choice trial was carried out. Feed and water
Table 2 Ingredients of the experimental diets ( $g / \mathrm{kg}$ as fed $)^{1}$

\begin{tabular}{lccc}
\hline \hline & \multicolumn{3}{c}{ Experimental diets } \\
\cline { 2 - 4 } Ingredients & $\mathrm{C}$ & $\mathrm{H} 1$ & $\mathrm{H} 2$ \\
\hline Ground corn & 480.0 & 480.0 & 480.0 \\
Soya bean meal & 440.3 & 314.5 & 255.0 \\
Hermetia illucens larvae meal (H) & 0.0 & 101.2 & 150.0 \\
Whole wheat & 15.2 & 67.5 & 87.5 \\
Calcium carbonate & 12.0 & 12.0 & 12.0 \\
Dicalcium phosphate & 8.00 & 6.00 & 6.00 \\
NaCl & 2.70 & 2.70 & 2.70 \\
L-Lysine & 0.50 & 1.30 & 2.50 \\
DL-Methionine & 1.80 & 1.80 & 1.80 \\
Vitamin-mineral premix & 2.50 & 2.50 & 2.50 \\
Soya bean oil & 37.0 & 10.5 & 0.0 \\
\hline \hline
\end{tabular}

${ }^{1}$ The nutritional value of the diets was calculated according to the Institut National del la Recherche Agronomique (INRA) procedures, by using the analytical composition of the raw materials which were provided by the feeding company.

${ }^{2}$ Vitamin and mineral premix provided the following per kg of diet: vitamin A, $11500 \mathrm{IU}$; cholecalciferol, $2100 \mathrm{IU}$; vitamin E (from dl-tocopherylacetate), $22 \mathrm{IU}$; vitamin $B_{12}, 0.60 \mathrm{mg}$; riboflavin, $4.4 \mathrm{mg}$; nicotinamide, $40 \mathrm{mg}$; calcium pantothenate, $35 \mathrm{mg}$; menadione (from menadione dimethyl-pyrimidinol), $1.50 \mathrm{mg}$; folic acid, $0.80 \mathrm{mg}$; thiamine, $3 \mathrm{mg}$; pyridoxine, $10 \mathrm{mg}$; biotin, $1 \mathrm{mg}$; choline chloride, $560 \mathrm{mg}$; ethoxyquin, $125 \mathrm{mg}$; Mn (from $\mathrm{MnSO}_{4} \cdot \mathrm{H}_{2} \mathrm{O}$ ), $65 \mathrm{mg} ; \mathrm{Zn}$ (from $\mathrm{ZnO}$ ), $55 \mathrm{mg} ; \mathrm{Fe}$ (from $\left.\mathrm{FeSO}_{4} \cdot 7 \mathrm{H}_{2} \mathrm{O}\right), 50 \mathrm{mg} ; \mathrm{Cu}$ (fromCuSO $\mathrm{CH}_{4} \cdot 5 \mathrm{H}_{2} \mathrm{O}$ ), $8 \mathrm{mg} ; \mathrm{I}$ (from $\left.\mathrm{Ca}\left(\mathrm{IO}_{3}\right)_{2} \cdot \mathrm{H}_{2} \mathrm{O}\right), 1.8 \mathrm{mg} ; \mathrm{Se}, 0.30 \mathrm{mg} ; \mathrm{Co}\left(\right.$ from $\left.\mathrm{CO}_{2} \mathrm{O}_{3}\right), 0.20 \mathrm{mg} ; \mathrm{Mo}, 0.16 \mathrm{mg}$.

Table 3 Chemical composition and energy content of the experimental diets $(\mathrm{g} / \mathrm{kg}$ as fed)

\begin{tabular}{lccc}
\hline \hline & \multicolumn{3}{c}{ Experimental groups } \\
\cline { 2 - 4 } & Control & H1 & H2 \\
\hline Dry matter & 898.0 & 897.0 & 896.0 \\
CP & 242.9 & 240.4 & 229.7 \\
Crude fat & 61.4 & 51.5 & 45.5 \\
Nitrogen-free extracts ${ }^{1}$ & 488.7 & 500.6 & 514.8 \\
Crude fibre $_{\text {Ash }}$ & 42.2 & 41.9 & 42.4 \\
Starch & 62.8 & 62.6 & 63.6 \\
Gross energy (MJ/kg) $^{2}$ & 299.2 & 323.2 & 300.8 \\
\hline \hline
\end{tabular}

${ }^{1}$ Calculated: $100-$ (water $+\mathrm{CP}+$ crude fat + crude fibre + ash).

${ }^{2}$ Analysed.

were provided ad libitum. Feeders were placed in complete randomized order and their position within cage was changed every 3 days. At the end of the experiment, the feed consumed from each feeder was determined on the cage basis. Free choice was expressed as gram of DM/100 $\mathrm{g}$ of LW.

Birds used for the digestibility trial and free choice test were returned to the farmer.

Chemical analysis of the diets and the excreta

Analyses of insect meal, experimental diets and freeze-dried excreta were carried out in duplicate using Association of Official Analytical Chemists (2000) methods to determine DM (method no. 934.01), CP (method no. 2001.11), crude 
fibre (method no. 978.10), ash (method no. 967.05) and starch (amyloglucosidase- $\alpha$-amylase, method no. 996.11) contents. Ether extract (EE) was determined after acid hydrolysis (EC, 1998). Gross energy (GE) was measured with an adiabatic bomb calorimeter (ISO, 1998). The amino acid concentration of $\mathrm{H}$ was analysed by EPTA NORD srl (Via Padova, Conselve, Italy, internal method). CP content of excreta was corrected for uric acid content which was analysed according the procedure described by Fievez et al. (2001) with the following modifications: the HPLC was an Agilent 1200 series (Agilent Technologies, Santa Clara, CA, USA), provided by a degasser, auto sampler, quaternary pump, column oven and diode-array detector. A $25 \mathrm{~cm}$ reversed phase column, $4.6 \mathrm{~mm}$ internal diameter and $5 \mu \mathrm{m}$ particle size was used (Supelcosil LC-18 Supelco cat. 58298, Sigma-Aldrich, St Louis, MO, USA). In front of this, a guard column was installed $(2 \mathrm{~cm}, 4.6 \mathrm{~mm} \varnothing)$. As we only aimed to determine uric acid content, another gradient was used and of each sample and standard solution, $50 \mu$ were injected. Detection was done by UV absorption at $205 \mathrm{~nm}$. The internal standard (allopurinol) was substituted with an external standard (acetonitrile) as allopurinol is degraded very soon and the derived products co-elute with the uric acid peak. The relation between the concentration of uric acid in the standard (between 2 and $20 \mu \mathrm{g} / \mathrm{ml}$ ) and the absolute peak area of the uric acid peak (retention time $(\mathrm{RT}) \pm 7.5 \mathrm{~min}$ ) was calculated by linear regression analysis. From the peak area of the uric acid peak in the sample, the concentration of uric acid in the sample could then be calculated. Urinary nitrogen was estimated at 1.2 times uric acid content (Terpstra and de Hart, 1973).

\section{Microbiological analysis}

On excreta, microbiological analysis considered total viable count (TVC: ISO 4833:2004), Enterobacteria (ISO 17604:2003 and ISO 21528-2:2004), total Coliforms (ISO 4831:2006 and ISO 4832:2006), sulphite-reducing Clostridia (APAT CNR-IRSA 7060 Manuals and guidelines. 29-2003: river and lake surface waters, and wastewater, also when treated), Lactobacillus spp. (ISO 15214:1998) and Bacillus spp. (UNI EN ISO 7932: 2005). Excreta $(20 \mathrm{~g}$ ) were placed into disposable sterile bags containing $180 \mathrm{ml}$ of sterile buffered peptone water and homogenized with a Colworth Stomacher 400 Circulator (Seward Ltd, Worthing, West Sussex, UK). Decimal logarithmic scale dilutions were included in specialized bacterial growth media and incubated according to the times and temperatures specified by the above-mentioned procedures. Results were expressed as colony-forming unit/g excreta. When no colonies were detected, the value $<10$ (respect to the minimal considered dilution) was considered.

\section{Slaughtering, carcass dissection, breast muscle measurements, cooking procedure and Warner-Bratzler shear force}

At 28 days of age, after feed removal, quails of the performance trial were individually weighed (slaughter weight (SW)) and transported to a commercial slaughterhouse (Quaja
Veneta ${ }^{\circledR}$ Società Cooperativa Agricola, Malo, VI, Italy) situated $8 \mathrm{~km}$ far from the farm. After $6 \mathrm{~h}$ fasting (from feed withdrawal until slaughtering), all birds were electrically stunned and processed under commercial conditions. Carcasses were bled, plucked, eviscerated and freed from head, neck, shanks and abdominal fat. After $1 \mathrm{~h}$ in the refrigeration tunnel $\left(+2^{\circ} \mathrm{C}\right)$, all carcasses were transported in chilled conditions to the MAPS Department of the University of Padova and stored at $+2^{\circ} \mathrm{C}$.

The following day, carcasses were individually weighed (CW) and dressing percentage was calculated as a percentage of the SW. From 50 quails/treatment, breast muscle was excised and the yield as a percentage of CW was then determined. Afterwards, colour measurements (Commission Internationale de l'Éclairage, 1976) were performed in the cranial and caudal part of the Pectoralis major muscle (RM200QC colorimeter; X-Rite Co., Neu-Isenburg, Germany) and considered lightness $\left(L^{*}\right)$, redness $\left(a^{*}\right)$ and yellowness $\left(b^{*}\right)$. Ultimate $\mathrm{pH}(\mathrm{pHu})$ was measured at the same sites of the pectoralis major muscle (portable pH metre FG2-Five $\mathrm{Go}^{\mathrm{TM}}$; Mettler Toledo, Greifensee, Switzerland; calibration at pH 4.0 and 7.0). The pHu as well as the colour values represented the average of the repeated measurements. All breast muscles were then vacuum-sealed by 10 and cooked in a water bath at $80^{\circ} \mathrm{C}$ until core temperature reached $74^{\circ} \mathrm{C}$. Meat samples were cooled under tap water, freed from plastic bags, dried and weighed to calculate cooking loss. Shear force was assessed with a TA-HDi Texture Analyzer (Stable Macro System, London, UK) on four cooked meat cores (diameter $1.25 \mathrm{~cm}$ ) per sample, sheared perpendicularly to muscle fibre direction with a Warner-Bratzler cell $(100 \mathrm{~kg}$ load cell, $2 \mathrm{~mm} / \mathrm{s}$ crosshead speed) fitted on the texturometer. Warner-Bratzler shear force (WBSF) was calculated by averaging four measurements per sample.

\section{Statistical analysis}

Growth performance, carcass and breast meat traits, nutrients apparent digestibility, nutritive values of diets and excreta microbial composition were subjected to a one-way ANOVA with experimental diet $(\mathrm{C}, \mathrm{H} 1$ and $\mathrm{H} 2)$ as fixed effect, following the GLM procedure of the SAS 9.1.3 statistical analysis software for Windows (SAS Institute, 2008). The experimental unit was the cage. A $\chi^{2}$ test with Marascuilo (1966) procedure was performed on mortality to detect the differences among treatments. For nutrients apparent digestibility and nutritive value of diets the model was initially covariated for LW of the animals. As covariate was never significant, the only effect of the experimental diet was considered. Preference test data were expressed as percentage of the total feed consumption per $100 \mathrm{~g}$ of LW. Data were preliminarily analysed by a PROC MIXED and animal was considered as random effect. As animal effect was not significant, a one-way ANOVA of the GLM procedures of SAS was performed and studied the effect of the experimental diet on the individual feed consumption. Differences were considered significant when $P<0.05$. 


\section{Results}

Quails performance and mortality

Table 4 shows the effect of different levels of $\mathrm{H}$ dietary inclusion on growth performance and mortality of growing

Table 4 Effect of the dietary inclusion of Hermetia illucens larvae meal $(H)$ on the live performance of broiler quails

\begin{tabular}{lcccccc}
\hline \hline & \multicolumn{3}{c}{ Experimental diets } & & \\
\cline { 2 - 5 } & Control & $H 1$ & H2 & & $P$-value & RSD \\
\hline Number (initial) & 150 & 150 & 150 & & \\
LW (g) & & & & & \\
$\quad$ Initial weight (10 days) & 73.7 & 74.1 & 74.2 & 0.1875 & 0.46 \\
$\quad$ Slaughter weight (28 days) & 222.1 & 225.3 & 222.5 & 0.6049 & 5.43 \\
BWG (g/day) & 8.25 & 8.40 & 8.24 & 0.6435 & 0.31 \\
FI (g/day) & 23.3 & 24.4 & 23.4 & 0.3696 & 1.28 \\
FCR & 2.83 & 2.90 & 2.86 & 0.6243 & 0.12 \\
Mortality (\%) & 0.20 & 0.20 & 0.00 & 0.6186 & 0.37 \\
\hline \hline
\end{tabular}

$\mathrm{LW}=$ live weight.

${ }^{1}$ Five replicates per treatment

Table 5 Effect of the dietary inclusion of Hermetia illucens larvae meal $(\mathrm{H})$ on the quail nutrients apparent digestibility and nutritive value of diets, microbiological composition of excreta and feed choice

\begin{tabular}{|c|c|c|c|c|c|}
\hline & \multicolumn{3}{|c|}{ Experimental diets } & \multirow[b]{2}{*}{$P$-value } & \multirow[b]{2}{*}{ RSD } \\
\hline & Control & $\mathrm{H} 1$ & $\mathrm{H} 2$ & & \\
\hline Number & 5 & 5 & 5 & & \\
\hline Initial live weight (LW) (g) & 171.0 & 174.0 & 173.0 & - & - \\
\hline Final LW (g) & 194.2 & 189.0 & 188.6 & 0.5670 & 9.06 \\
\hline Average LW (g) & 182.7 & 181.6 & 180.6 & 0.9160 & 7.90 \\
\hline Dry matter (DM) intake (g) & 51.2 & 45.0 & 45.5 & 0.0784 & 4.30 \\
\hline DM intake $(\mathrm{g} / 100 \mathrm{~g} \mathrm{LW})$ & 28.0 & 24.8 & 25.2 & 0.0818 & 2.23 \\
\hline Excreta (g DM) & 23.5 & 18.6 & 20.4 & 0.1612 & 3.84 \\
\hline \multicolumn{6}{|l|}{ Apparent digestibility (\%) } \\
\hline DM & 54.0 & 58.9 & 55.2 & 0.5429 & 7.08 \\
\hline Organic matter & 58.4 & 62.9 & 59.1 & 0.5201 & 6.57 \\
\hline$C P$ & 45.1 & 42.9 & 34.0 & 0.1017 & 7.92 \\
\hline Ether extract & $92.9^{\mathrm{A}}$ & $82.5^{\mathrm{B}}$ & $89.6^{\mathrm{A}}$ & 0.0001 & 2.56 \\
\hline Starch & 93.9 & 95.7 & 95.7 & 0.2736 & 1.99 \\
\hline Energy & 62.0 & 65.3 & 63.1 & 0.6611 & 5.88 \\
\hline \multicolumn{6}{|l|}{ Nutritive value } \\
\hline $\begin{array}{l}\text { Metabolizable energy } \\
\text { (MJ/kg DM) }\end{array}$ & 11.8 & 12.2 & 12.4 & 0.6869 & 1.13 \\
\hline \multicolumn{6}{|l|}{$\begin{array}{l}\text { Microbiological composition } \\
\text { of excreta (CFU/g) }\end{array}$} \\
\hline Total viable count & 8.24 & 8.30 & 8.44 & 0.8778 & 0.60 \\
\hline Enterobacteriaceae & 2.50 & 2.80 & 0.00 & 0.3153 & 3.03 \\
\hline Coliforms & 7.38 & 8.00 & 8.23 & 0.3225 & 0.89 \\
\hline Clostridia & 4.38 & 5.79 & 4.83 & 0.2183 & 1.23 \\
\hline Lactobacillus spp. & 8.08 & 8.44 & 8.41 & 0.8331 & 1.04 \\
\hline Bacillus spp. & 6.70 & 6.70 & 6.70 & - & - \\
\hline \multicolumn{6}{|l|}{ Feed choice trial } \\
\hline $\begin{array}{l}\text { Feed intake (g DM/100 g } \\
\text { LW) }\end{array}$ & 44.1 & - & 53.8 & 0.0642 & 13.8 \\
\hline
\end{tabular}

$\mathrm{CFU}=$ colony-forming unit.

${ }_{A}^{A} B$ Means in a row with different superscripts differ significantly $(P<0.01)$. broiler quails. No differences due to dietary treatment were observed: quails showed the same final SW, body weight gain (BWG), feed intake (FI), feed conversion ratio (FCR) and mortality rate in $\mathrm{C}, \mathrm{H} 1$ and $\mathrm{H} 2$ dietary groups.

\section{Nutrients apparent digestibility, excreta microbial composition and feed choice}

Independently to the dietary treatment, quails showed the same final LW, DM intake and excreta production (Table 5). Apparent digestibility of nutrients was overall comparable among the three groups. The only exception was the $\mathrm{EE}_{\text {, }}$ whose digestibility was the highest in $\mathrm{C}$ and $\mathrm{H} 2$ animals $(P<0.001)$. Metabolizable energy of diets, expressed as $\mathrm{MJ} / \mathrm{kg} \mathrm{DM}$, was similar in all three dietary groups. Similarly, also the microbial composition of excreta $\left(\log _{10}\right)$ did not differ among dietary treatments for TVC, Enterobacteriaceae, total Coliforms, Clostridia, Lactobacillus spp. and Bacillus spp. Even if the statistical significance was below the threshold $(P=0.0642)$, when quails were given a choice between $\mathrm{C}$ and $\mathrm{H} 2$ diets, they tended to prefer the $\mathrm{H} 2$ diet (44.1\% v. 53.8\% for Control and H2 diet, respectively).

\section{Carcass and breast meat traits}

Table 6 depicts the effect of $\mathrm{H}$ dietary inclusion on quails carcass weight and dressing percentage, breast muscle weight, yield, pHu, colour, cooking loss and WBSF. Dietary inclusion of black soldier fly larvae meal reduced $\mathrm{pHu}$ of quail Pectoralis major, which was lower in $\mathrm{H} 1$ and $\mathrm{H} 2$ groups compared with the C (5.68 and 5.67 v. 5.76 , respectively). Redness index $\left(a^{*}\right)$ was significantly affected by dietary treatment and showed its highest and lowest values for $\mathrm{H} 1$ and $\mathrm{H} 2$ groups, whereas in $\mathrm{C}$ breast meat it was intermediate $(P<0.05)$. Cooked breast meat was significantly lighter in $\mathrm{H} 2$ group compared with $\mathrm{H} 1$

Table 6 Effect of the dietary inclusion of Hermetia illucens larvae meal $(H)$ on the carcass and breast meat traits of broiler quails

\begin{tabular}{lllllll}
\hline \hline & \multicolumn{3}{c}{ Experimental groups } & & \\
\cline { 2 - 4 } & Control & $\mathrm{H} 1$ & $\mathrm{H} 2$ & P-value & RSD \\
\hline Number (initial) & 150 & 150 & 150 & & \\
$\quad$ Carcass weight & 141.5 & 145.9 & 142.9 & 0.1970 & 1.64 \\
$\quad(\mathrm{CW})(\mathrm{g})$ & & & & & \\
$\quad$ Dressing (\% CW) & 64.1 & 64.3 & 64.7 & 0.4430 & 0.34 \\
Number & 50 & 50 & 50 & & \\
Breast meat (g) & 43.8 & 45.0 & 43.7 & 0.4495 & 0.86 \\
Breast meat yield & 30.7 & 30.8 & 30.7 & 0.9737 & 0.37 \\
(\% CW) & & & & & \\
pHu & $5.76^{\mathrm{A}}$ & $5.68^{\mathrm{B}}$ & $5.67^{\mathrm{B}}$ & $<0.0001$ & 0.02 \\
$L^{*}$ value & 54.8 & 55.1 & 54.4 & 0.3869 & 0.41 \\
$a^{*}$ value & $0.81^{\mathrm{ab}}$ & $1.13^{\mathrm{a}}$ & $0.46^{\mathrm{b}}$ & 0.0371 & 0.22 \\
$b^{*}$ value & 7.75 & 8.14 & 7.85 & 0.4179 & 0.22 \\
Cooked breast (g) & $33.1^{\mathrm{ab}}$ & $34.6^{\mathrm{a}}$ & $32.3^{\mathrm{b}}$ & 0.0436 & 1.01 \\
Cooking loss (\%) & $24.7^{\mathrm{B}}$ & $23.4^{\mathrm{B}}$ & $28.1^{\mathrm{A}}$ & $<0.0001$ & 0.83 \\
WBSF (kg/cm $\left.{ }^{2}\right)$ & $14.6^{\mathrm{AB}}$ & $12.3^{\mathrm{B}}$ & $15.6^{\mathrm{A}}$ & 0.0005 & 0.71 \\
\hline \hline
\end{tabular}

pHu = ultimate $\mathrm{pH} ; \mathrm{WBSF}=$ Warner-Bratzler shear force.

${ }_{\mathrm{a}, \mathrm{b}}$ Means in a row with different superscripts differ significantly $(P<0.05)$.

${ }^{A}, B$ Means in a row with different superscripts differ significantly $(P<0.01)$. 
one $(P<0.05)$. This resulted from a higher cooking loss $(P<0.05)$ of $\mathrm{H} 2$, which resulted also in tougher meat $(P<0.001)$. On the other hand, cooked breast from $\mathrm{H} 1$ group was the heaviest and the most tender $(P<0.001)$.

\section{Discussion}

The current study is the first in testing defatted black soldier fly ( $H$. illucens) larvae meal in quail diets reared under intensive conditions. The amino acid concentration of $\mathrm{H}$ (Table 1) was comparable with those of a meat and bone meal and a meat meal (Ravindran et al., 1999). The most abundant indispensable amino acids were valine and leucine, whereas alanine and glutamic acid were the most abundant dispensable amino acids. The amino acid concentration of $\mathrm{H}$ differed from the full-fat black soldier fly larvae meal presented by De Marco et al. (2015): regarding indispensable amino acids, lysine, methionine, arginine and histidine contents were lower in $\mathrm{H}$ compared with those of the above-mentioned study, whereas for isoleucine, leucine, phenylalanine, threonine and valine the situation was reversed. Growth performance and mortality of growing quails of the present experiment (Table 4) were consistent with the reference values recorded in the commercial farm in which the trial was conducted, and also with literature results (Mehri et al., 2015). From the results of the chemical composition of the diets (Table 3), it was observed that the $\mathrm{H} 2$ diet had the lowest crude fat and CP contents. In addition, the GE slightly differed between $\mathrm{H} 1$ and $\mathrm{H} 2$ treatments, being the highest in $\mathrm{H} 2$. Despite this, the inclusion of $10 \%$ and $15 \% \mathrm{H}$ meal in the diet of growing quails (from 10 to 28 days of age) provided results comparable with those of quails fed with conventional soya bean meal and oil-based diets (C). As the trial was conducted under intensive conditions, it could be stated that $H$. illucens meal can be a suitable ingredient for broiler quails diets in the growing period, thus confirming to be one of the most promising insects for industrial feed production in the Western world (Veldkamp and Bosch, 2015). In the only other study, testing $H$. illucens in starter broiler diets, a full-fat meal provided similar performance results to those of broilers fed diets containing conventional fishmeal (Elwert et al., 2010). Black soldier fly larvae are notably rich in key nutrients such as CP with a high biological value, fat and minerals (Makkar et al., 2014), thus our positive findings were expected. In addition, chitin which is a polysaccharide constituting insects and crustaceans exoskeleton, was reported to act as prebiotic by improving the immune response of birds (Bovera et al., 2015) and by increasing the caecal production of butyric acid (Khempaka et al., 2011), which is considered the prime energy source for enterocytes. The latter would result in an enhanced intestinal blood flow through the intestine, thus ameliorating tissue oxygenation and nutrient transport and absorption (Mahdavi and Torki, 2009). In fact, results regarding other insect species with potential interest as feed for farm animals, similar results than those of our study were observed also when Tenebrio molitor meal was included in the diet of broiler chickens as a total replacement of soya bean meal (Bovera et al., 2015 and 2016).

Apparent digestibility of CP, EE and starch (Table 5) was similar to that usually reported in literature for quail, whereas DM and organic matter (OM) apparent digestibility was lower than common findings (Sahin et al., 2002). The latter results might be explained by the environmental temperature during the digestibility trial which was around $30^{\circ} \mathrm{C}$, thus presumably stressing the animals. Poultry species are sensitive to heat which causes in vivo oxidative stress and which is detrimental also for their appetite, LW gain and feed efficiency (Sahin et al., 2006).

Our results showed that the dietary inclusion on $\mathrm{H}$. illucens meal did not impair the overall apparent digestibility of nutrients both for $\mathrm{H} 1$ and $\mathrm{H} 2$, thus confirming the positive findings of De Marco et al. (2015) for chicken broilers. However, the lower EE digestibility of $\mathrm{H} 1$ diet compared with $\mathrm{C}$ and $\mathrm{H} 2$ ones was quite surprising as a different trend was expected: $\mathrm{C}>\mathrm{H} 1>\mathrm{H} 2$. In addition, despite statistical significance did not support this assumption probably as a result of a large variance in data, CP digestibility showed a decreasing trend from $\mathrm{C}$ to $\mathrm{H} 2$ diets, with H2 group showing a relatively $24.6 \%$ lower $C P$ apparent digestibility compared with $C$ diet $(P=0.1017)$. $H$. illucens pre-pupae is known to contain about $87 \mathrm{~g} / \mathrm{kg}$ DM chitin, which can have a negative effect on nutrients digestion (mainly protein and lipid fractions), especially when animals have no chitinolytic activity (Kroeckel et al., 2012). In fact, when chicken diets were supplemented with chitin, a lower duodenal digestibility of CP and OM compared with a control diet was observed (Razdan and Pettersson, 1994). A dietary inclusion of $T$. molitor larvae meal in chicken diet, lowered the apparent ileal digestibility of DM, CP and OM, even though growth performance was not negatively affected (Bovera et al., 2015). A possible way to solve this drawback, related to the use of insects as feed ingredient, would be the partial chitin removal through high pressure processing, which would also disrupt the link between some chitinbound proteins, ultimately improving their quality (Rumpold and Schlüter, 2013).

H. illucens larvae have a high content of lauric acid (C12:0) which is known for being a natural antimicrobial agent, which act by disrupting cell membrane, being thus effective for the control of various foodborne pathogens (Kim and Rhee, 2016). In addition, larval secretions of $H$. illucens were reported to be very rich in substances with novel antimicrobial properties (Park et al., 2014), which are mainly attributable to the humoral response of insects' immune system, involving the production of peptides with antimicrobial activity which are secreted in the haemolymph. On the basis of the above-mentioned considerations, a possible positive effect on intestinal microbiota was initially hypothesized which, however, found no confirmation in the results of excreta microbial composition, presumably due to the optimal health status of all quails subjected to the present digestibility trial. In fact, microbial composition 
of quails excreta of the present study was in line with results reported literature for healthy quails (Mehri et al., 2015).

To the best of our knowledge, this represents the first feed choice trial testing the inclusion of an insect meal in the diet of growing broiler quails. Results on chicken broilers were consistent with our findings: when free-range chicken fed either a control diet or a diet in which gluten meal was replaced with $T$. molitor meal, the same average daily feed intake was observed (Biasato et al., 2016). Similar results were found when a $T$. molitor meal replaced soya bean meal with hulls in the diet for broiler chickens (Bovera et al., 2015).

The inclusion of black soldier fly larvae meal in the diet of growing quails provided satisfactory results also in terms of carcass weight and dressing out percentage, as well as breast weight and yield to CW and meat quality (Table 6). Despite breast meat pHu differed in $\mathrm{C} v$. $\mathrm{H} 1$ and $\mathrm{H} 2$ quails, all three $\mathrm{pH}$ values (5.76 v. 5.68 and 5.67 , respectively; $P<0.0001)$ were in the normal range reported for quails (Tavaniello et al., 2014). However, differences in pH could be ascribable to a different muscle glycogen content. Muscle $\mathrm{pHu}$ is a key contributing factor to meat quality intended as colour, moisture retention and cooking yield. A meat with $\mathrm{pH}$ close to the isoelectric point (5.2 to 5.5) of its constituting proteins results in a lower water holding capacity, thus giving a more intense cooking loss. This was partly the case of our study: the breast meat from $\mathrm{H} 2$ group showed lower $\mathrm{pHu}$, thus generating higher cooking loss. Despite this, the final quality of meat in terms of tenderness did not change as WBSF values were similar to those recorded for $\mathrm{C}$ meat. Appearance and texture are considered the two most important quality attributes for poultry. Based on the physical results obtained, quails breasts do not seem to be affected by dietary treatments, substantially.

Breast meat from $\mathrm{H} 1$ quails was the most tender and the reddest. It is well established that pre-slaughter conditions intended as antemortem temperature, stress and excitement just before slaughter affect the postmortem metabolism of muscle and thus meat quality. However, as handling and slaughtering procedures were exactly the same for all the quails of the present study, a causative agent is to be searched elsewhere. In literature, studies dealing with the effect of insect meals on meat quality traits are very scarce and our findings do not seem to confirm those in literature: when a $T$. molitor larvae meal was fed to chicken broilers, the pHu value and cooking loss of their breast fillets was higher than that of birds fed with the conventional diet based on soya bean, with no change in meat colour (Bovera et al., 2016).

In conclusion, the present research provided new data and knowledge on the potential application and benefits of using insects as new feed ingredients for broiler quails. H. illucens larvae meal showed to be a promising feed ingredient (up to $15 \%$ inclusion level) for growing broiler quails, as a partial replacement to the common soya bean meal and soya bean oil. In fact, digestibility of nutrients, productive performance, carcass and meat quality were overall satisfactory. Further research efforts are necessary to deeply investigate the impact of different insects larvae meal on intestinal morphology. In addition, the effects of insect feed on meat quality traits and sensory properties should be carefully investigated for both consumers acceptance as well as for marketing purposes.

\section{Acknowledgements}

Authors would like to express their gratitude to Rino Cailotto for providing the quails, for the technical support and for allowing us to conduct the study in his farm. Special thanks to Quaja Veneta ${ }^{\circledR}$ Società Cooperativa Agricola (Malo, VI, Italy) for slaughtering and for the technical help which represented a fundamental basis to conduct a successful experiment. Finally, authors would also like to acknowledge the feed company NATCOR Srl (San Tomio di Malo, VI, Italy) for supplying the raw materials for the experimental diets.

\section{References}

Association of Official Analytical Chemists 2000. Official methods of analysis, 17th edition. AOAC, Arlington, VA, USA.

Biasato I, De Marco M, Rotolo L, Renna M, Lussiana C, Dabbou S, Capucchio MT, Biasibetti E, Costa P, Gai F, Pozzo L, Dezzutto D, Bergagna S, Martinez S, Tarantola M, Gasco L and Schiavone A 2016. Effects of dietary Tenebrio molitor meal inclusion in free-range chickens. Journal of Animal Physiology and Animal Nutrition, doi:10.1111/jpn.12487.

Bovera F, Loponte R, Marono S, Piccolo G, Parisi G, laconisi V, Gasco L and Nizza A 2016. Use of Tenebrio molitor larvae meal as protein source in broiler diet: effect on growth performance, nutrient digestibility, and carcass and meat traits. Journal of Animal Science 94, 1-9.

Bovera F, Piccolo G, Gasco L, Marono S, Loponte R, Vassalotti G, Mastellone V, Lombardi P, Attia YA and Nizza A 2015. Yellow mealworm larvae (Tenebrio molitor, L.) as a possible alternative to soybean meal in broiler diets. British Poultry Science 56, 569-575.

Commission Internationale de l'Éclairage 1976. Official recommendations on uniform colour space, colour difference equations and metric colour terms. CIE Publication no. 15 (E-1.3.1), suppl. 2. Bureau Central de la CIE, Paris, France.

De Marco M, Martínez S, Hernandez F, Madrid J, Gai F, Rotolo R, Belforti M, Bergero D, Katz H, Dabbou S, Kovitvadhi A, Zoccarato I, Gasco L and Schiavone A 2015. Nutritional value of two insect larval meals (Tenebrio molitor and Hermetia illucens) for broiler chickens: apparent nutrient digestibility, apparent ileal amino acid digestibility and apparent metabolizable energy. Animal Feed Science and Technology 209, 211-218.

EC 1998. Commission Directive 98/64/EC of 3 September 1998 establishing Community methods of analysis for the determination of amino acids, crude oils and fats, and olaquindox in feeding stuffs and amending Directive 71/393/EEC. Official Journal of the European Union L257, 14.

Elwert C, Knips I and Katz P 2010. A novel protein source: maggot meal of the black soldier fly (Hermetia illucens) in broiler feed. In 11. Tagung Schweine- und Geflügelernährung, 23.-25. November 2010 Lutherstadt Wittenberg (ed. $M$ Gierus, H Kluth, M Bulang and H Kluge). Institut für Agrar- und Ernährungswissenschaften, Universität Halle-Wittenberg, Halle-Wittenberg, 140-142.

Fievez V, De Fauw K, Notteboom K and Demeyer D 2001. Effect of level and origin of rumen degradable nitrogen on rumen microbial growth and nitrogen utilization efficiency of animals fed maize silage at maintenance. Reproduction, Nutrition, Development 41, 349-364.

Food and Agriculture Organization of the United Nations (FAO) 2010. The state of world fisheries and aquaculture 2010. FAO, Fisheries and Aquaculture Department, Rome, Italy. Retrieved March 17, 2016, from http://www.fao.org/ docrep/013/i1820e/i1820e00.htm.

Food and Agriculture Organization of the United Nations (FAO) 2013. Edible insects - future prospects for food and feed security. FAO Forestry Paper No. 171, FAO, Rome, Italy, p. ix. 


\section{Cullere, Tasoniero, Giaccone, Miotti-Scapin, Claeys, De Smet and Dalle Zotte}

Food and Agriculture Organization of the United Nations (FAO) 2014. Insects to feed the World. 1st International Conference, 14-17 May 2014, Wageningen (Ede), the Netherlands, p. V.

International Organization for Standardization (ISO) 1998. Animal feeding stuffs, animal products and faeces or urine. Determination of gross calorific value - Bomb calorimetric method. Reference number 9831, prepared by Technical Committee ISO/TC 34, Agricultural food products, Subcommittee SC 10, Animal feeding stuffs.

Khempaka S, Chitsatchapong C and Molee W 2011. Effect of chitin and protein constituents in shrimp head meal on growth performance, nutrient digestibility, intestinal microbial populations, volatile fatty acids, and ammonia production in broilers. Journal of Applied Poultry Research 20, 1-11.

Kim SA and Rhee MS 2016. Highly enhanced bactericidal effects of medium chain fatty acids (caprylic, capric, and lauric acid) combined with edible plant essential oils (carvacrol, eugenol, b-resorcylic acid, trans-cinnamaldehyde, thymol, and vanillin) against Escherichia coli 0157:H7. Food Control 60, 447-454.

Kroeckel S, Harjes A-GE, Roth I, Katz H, Wuertz S, Susenbeth A and Schulz C 2012. When a turbot catches a fly: evaluation of a pre-pupae meal of the Black Soldier Fly (Hermetia illucens) as fish meal substitute - growth performance and chitin degradation in juvenile turbot (Psetta maxima). Aquaculture 364-365, 345-352.

Mahdavi R and Torki M 2009. Study on usage period of dietary protected butyric acid on performance, carcass characteristics, serum metabolite levels and humoral immune response of broiler chickens. Journal of Animal and Veterinary Advances 8, 1702-1709.

Makkar HPS, Tran G, Heuze V and Ankers P 2014. State-of-the-art on use of insects as animal feed. Animal Feed Science and Technology 197, 1-33.

Marascuilo LA 1966. Large-sample multiple comparisons. Psychological bulletin 65, 280-290.

Martínez-Sánchez A, Magaña C, Saloña M and Rojo S 2011. First record of Hermetia illucens (Diptera: Stratiomyidae) on human corpses in Iberian Peninsula. Forensic Science International 206, e76-e78.

Mehri M, Sabaghi V and Bagherzadeh-Kasmani F 2015. Mentha piperita (peppermint) in growing Japanese quails diet: performance, carcass attributes, morphology and microbial populations of intestine. Animal Feed Science and Technology 207, 104-111.

Nguyen TTX, Tomberlin JK and Vanlaerhoven S 2015. Ability of black soldier fly (Diptera: Stratiomyidae) larvae to recycle food waste. Environmental Entomology 44, 406-410.

National Research Council, subcommittee on Poultry Nutrition 1994. Nutrient requirements of Ring-Necked Pheasants, Japanese Quail, and Bobwhite Quail. In Nutrient requirements of poultry, 9th revised edition, (ed. National Academy Press), pp. 44-45. National Academy of Sciences, Washington, DC, USA.

Oluokun JA 2000. Upgrading the nutritive value of full-fat soyabeans meal for broiler production with either fishmeal or black soldier fly larvae meal (Hermetia illucens). Nigerian Journal of Animal Science 3, doi:10.4314/tjas. v3i2.49768.
Park S-I, Chang BS and Yoe SM 2014. Detection of antimicrobial substances from larvae of the black soldier fly, Hermetia illucens (Diptera: Stratiomyidae). Entomological Research 44, 58-64.

Ravindran V, Hew LI, Ravindran G and Bryden WL 1999. A comparison of ileal digesta and excreta analysis for the determination of amino acid digestibility in food ingredients for poultry. British Poultry Science 40, 266-274.

Razdan A and Pettersson D 1994. Effect of chitin and chitosan on nutrient digestibility and plasma lipid concentrations in broiler chickens. British Journal of Nutrition 72, 277-288.

Rumpold BA and Schlüter OK 2013. Potential and challenges of insects as an innovative source for food and feed production. Innovative Food Science and Emerging Technologies 17, 1-11.

Sahin K, Onderci M, Sahin N, Gursu MF, Khachik F and Kucuk 0 2006. Effects of lycopene supplementation on antioxidant status, oxidative stress, performance and carcass characteristics in heat-stressed Japanese quail. Journal of Thermal Biology 31, 307-312.

Sahin K, Sahin N and Onderci M 2002. Vitamin E supplementation can alleviate negative effects of heat stress on egg production, egg quality, digestibility of nutrients and egg yolk mineral concentrations of Japanese quails. Research in Veterinary Science 73, 307-312.

Sánchez-Muros M-J, Barroso FG and Manzano-Agugliaro F 2014. Insect meal as a renewable source of food for animal feeding: a review. Journal of Cleaner Production 65, 16-27.

Sealey WM, Gaylord TG, Barrows FT, Tomberlin JK, McGuire MA, Ross C and St-Hilaire S 2011. Sensory analysis of rainbow trout, Oncorhynchus mykiss, fed enriched black soldier fly prepupae, Hermetia illucens. Journal of the World Aquaculture Society 42, 34-45.

Statistical Analysis Software for Windows 2008. Statistics version 9.1.3 ed. SAS Institute, Cary, NC, USA.

St-Hilaire S, Sheppard C, Tomberlin JK, Irving S, Newton L, McGuire MA, Mosely EE, Hardy R and Sealey W 2007. Fly prepupae as a feedstuff for rainbow trout Onchorynchus mykiss. Journal of the World Aquaculture Society 38, 59-67.

Tavaniello S, Maiorano G, Siwek M, Knaga S, Witkowski A, Di Memmo M and Bednarczyk M 2014. Growth performance, meat quality traits, and genetic mapping of quantitative trait loci in 3 generations of Japanese quail populations (Coturnix japonica). Poultry Science 93, 2129-2140.

Terpstra K and de Hart N 1973. The estimation of urinary nitrogen and faecal nitrogen in poultry excreta. Zeitschrift für Tierphysiologie Tierernährung und Futtermittelkunde 32, 306-320.

Tran G, Heuzé V and Makkar HPS 2015. Insects in fish diets. Animal Frontiers 5, 37-44.

Veldkamp T and Bosch G 2015. Insects: a protein-rich feed ingredient in pig and poultry diets. Animal Frontiers 5, 45-50.

Veldkamp T, van Duinkerken G, van Huis A, Lakemond CMM, Ottevanger E, Bosch $G$ and van Boekel MAJS 2012. Insects as a sustainable feed ingredient in pig and poultry diets - a feasibility study. Wageningen UR Livestock Production Wageningen, the Netherlands, report no. 638, pp. 1-48. 